\title{
Novel Processed Cheese Production Using Lycopene Oil Obtained By Green-Extraction Technique of Tomato Peels Waste
}

\author{
Abeer F Zayan', Amr M Bakry4*, Tamer S AbdulAlim', Radwan H M², M. Abouelnaga ${ }^{4}$, Waseem Safdar ${ }^{5}$, Pedro H. Campelo ${ }^{6}$, Marwan \\ M.A. Rashed ${ }^{5}$, Md Ramim Tanver Rahman ${ }^{5}$, Zafarullah Muhammad ${ }^{3}$, Ahmed Taha $^{3}$ \\ ${ }^{1}$ Dairy Science and Technology Research Department, Food Technology Research Institute, Agriculture Research Centre, Giza12619Egypt. \\ ${ }^{2}$ Horticulture Crops Research Department, Agriculture Research Centre, Giza 12619, Egypt. \\ ${ }^{3}$ College of Food Science and Technology and MOE Key Laboratory of Environment Correlative Dietology, Huazhong Agricultural University, \\ Wuhan 430070, China \\ ${ }^{4}$ Department of Dairy Science, Faculty of Agriculture, Suez Canal University, Ismailia 41522, Egypt \\ ${ }^{5}$ State Key Laboratory of Food Science and Technology, School of Food Science and Technology, Jiangnan University, Wuxi, 214122, Jiangsu, PR \\ China
}

${ }^{6}$ Faculty of Agrarian Science, Federal University of Amazonas, Manaus, AM, Brazil

*Corresponding Author: Amr M Bakry, College of Food Science and Technology and MOE Key Laboratory of Environment Correlative Dietology, Huazhong Agricultural University, Wuhan, China. Department of Dairy Science, Faculty of Agriculture, Suez Canal University, Ismailia, Egypt

Received date: December 13, 2020; Accepted date: February 06, 2021; Published date: February 20,2021

Citation: Abeer F Zayan., Amr M Bakry., Tamer S AbdulAlim., Radwan H M M., Abouelnaga, et al (2021) Novel Processed Cheese Production Using Lycopene Oil Obtained By Green-Extraction Technique of Tomato Peels Waste. J. Nutrition and Food Processing, 4(1); DOI: $10.31579 / 2637-8914 / 035$

Copyright: () 2021 Amr M Bakry, This is an open access article distributed under the Creative Commons Attribution License, which permits unrestricted use, distribution, and reproduction in any medium, provided the original work is properly cited.

\begin{abstract}
Extracted lycopene oil of tomato peels waste using green-extraction technique may be used as a convenient alternative to butter in processed cheese manufacturing. The effects of partial substitution of butter by lycopene oil at ratio of $25 \%, 50 \%$, and $75 \%$ were evaluated, in comparison with cheeses produced only with butter. The substitution of butter by lycopene oil increased dry matter, ash, lycopene content, antioxidant activity, meltability and sensorial characteristics of processed cheese. While, the firmness value was decreased with increasing level of incorporated lycopene oil. The present study displays that the substitution of butter by lycopene oil obtained by green-extraction technique of tomato peels waste in processed cheese can be used as a substitute process for decreasing saturated fats in dairy products with keeping other desired characteristics of the product.
\end{abstract}

Keywords: processed cheese; green extract; phenolic content; sensory evaluation; lycopene

Running head: processed cheeses

Graphical Abstract

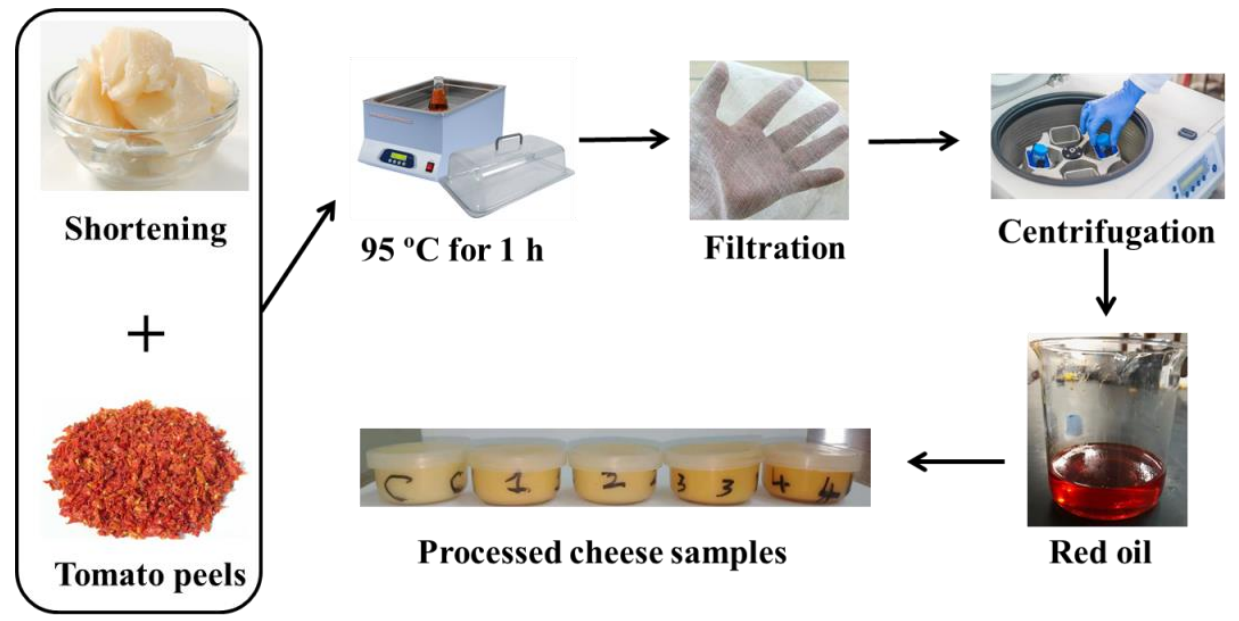




\section{Introduction:}

Processed cheese is one of the best important sources of calcium and protein in dairy products as well as other nutrients such as minerals and vitamins. It is characterized by a high degree of stability and decreased need to cooling during storage $[1,2]$. Processed cheese spreads are composed of various components generally made from a mixture of dairy, for example, butteroil, cream, butter, dried milk, caseinates and dried whey protein and dairy-free components and added substances, for example, colorants and hydrocolloids [3]. Besides, the emulsifying salts, for example, sodium lactate, calcium lactate, sodium citrates, potassium citrates, calcium citrates, sodium phosphates, potassium phosphates, diphosphates and polyphosphates are among the main components of processed cheeses production [3]. Frequently, the manufacturers are looking for novel methods to increase the function characteristics of the processed cheese products in order to increase consumer acceptance of these products [2].
Tomatoes, Lycopersicon esculentum, are one of the biggest crops around the world in terms of consumption. Nearly, more than one hundred million tons of tomatoes fruits produced every year all over the world [4]. During manufacturing process of tomato products such as purees, pastes, juices, canned tomatoes and sauces, a tremendous amounts of waste named as tomato pomace such as peels, pulp and tomato seeds are produced [5]. The tomato pomace is considered as non-important waste, which causes a serious environmental issue when disposed of [6]. However, this waste is a rich source of various valuable bioactive compounds such as lycopene, polyphenols, ascorbic acid, terpenes, $\beta$ carotene, sterols and tocopherols [7]. Out of all these various bioactive compounds, lycopene is by far the most important among them which is considered not manufactured dye that pays the red color to the vegetables and fruits [8]. It can be used in food industry as natural coloring substance in order to avoid the harmful effects of artificial food colorants. Lycopene $\left(\mathrm{C}_{40} \mathrm{H}_{56}\right)$ is a component which having an open-chain structure, openchain polyene hydrocarbon with thirteen double covalent bonds, out of which eleven are integrated in a linear order (Figure. 1) [8].

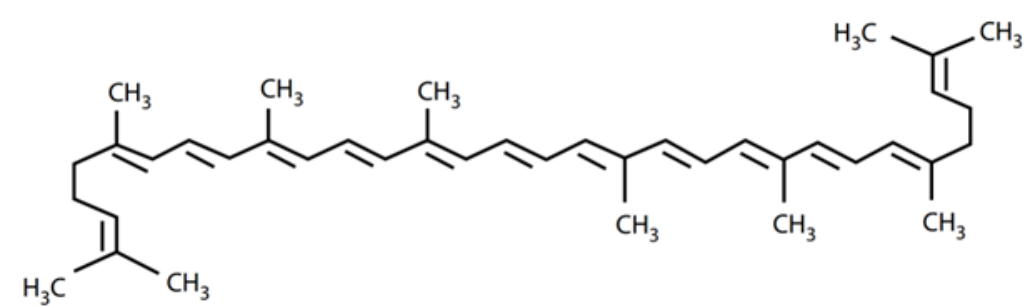

Figure 1: Molecular Structure of Lycopene

Lycopene is considered as one of the most powerful antioxidants because its variety of conjugated double bonds makes it an excellent quencher of free radicals [4]. With growing attention and consciousness of its multiple positive effects, lycopene has been utilized in enriched foods and nutraceuticals. Moreover, it has been used in pharmaceutical, cosmetic and biomedical industries [9]. Because, of its potential antioxidant property it is useful in the treatment of cardiovascular diseases. Also, it has an effective role in breast, colon, prostate and lung cancer prevention [10-13]. Moreover, it has protective activity against chronic diseases, and skin cancers [14]. Lycopene is almost present in all parts of ripe tomato fruit such as water insoluble part, peel and pulp. However, the largest amount of lycopene is mostly found in peel by $90 \%$ [5]. George, Kaur [15] observed that the amount of lycopene in peels ranged from 48 to $141 \mathrm{mg} \mathrm{kg}^{-1}$ and decreased in pulp of tomatoes (20 to $69 \mathrm{mg} \mathrm{kg}^{-1}$ ) from different cultivars.

Generally, extraction of lycopene from tomatoes is implemented by chemical extraction utilizing organic solvents such as n-hexyl hydride, propanone, ethyl alcohol, trichloromethane, heptane, oxolane [16-18]. Nevertheless, the organic solvents used in the extraction of lycopene poses a multitude of disadvantages such as toxicity, difficulty to dispose of, hazards to handle with, costly, low quality and length of extraction period [19]. In last decades, the techniques for lycopene extraction from tomatoes have been developed such as supercritical $\mathrm{CO}_{2}$ technique. This technique had several advantages such as good yield rate, shorter extraction period and high quality [19]. However, it takes a big amount of energy in the extraction process. Moreover, it requires a great amount of $\mathrm{CO}_{2}$ during the operation. Furthermore, the limited solubility of lycopene in $\mathrm{CO}_{2}$ imposes the use of modifiers and co-solvents to get the most out of lycopene yield [19]. Newly, the extraction methods for lycopene have been developed which depended on using the green chemistry tools. Sachindra and Mahendrakar [20] have been used sunflower oil as alternative solvents to obtain carotenoids from the wastes of the shrimp processing industries. Shrimp waste was mixed with sunflower oil at a ratio of $1: 2$ and heated at $70{ }^{\circ} \mathrm{C}$ for $150 \mathrm{~min}$ in order to obtain a higher carotenoid yield. In another study, Li, Fabiano-Tixier [21] have been used the same oil in taking out of volatile compounds from basil seeds. In addition, it has been proven that carotenoids extracted from gardenfresh carrots with sunflower oil, through ultrasound, is a green biological refining technique [22]. Choksi and Joshi [23] reported that the bioavailability of lycopene increased with boiling of tomato juice for one hour in the presence of corn oil. As alternative solvent, vegetable (palm) oil based shortening in our study was used in extraction of lycopene (lycopene oil). Al-Neshawy and Al-Eid [24] demonstrated that palm oil was a valuable ingredient for shortening formulation. Additionally, replacement of butterfat with a shortening is the important first step in duplication of dairy products. Therefore, the goal of the present study was to examine the effects of the total or partial substitution of butter by lycopene oil on physiochemical, rheological and sensorial properties of processed cheese.

\section{MATERIALS AND METHODS}

\section{Materials}

Ras cheese (1 month old), fresh kariesh cheese and fresh butter were brought from Dairy Department, Faculty of Agriculture, Cairo University, Egypt. Cheddar cheese (ripened for 8 months) was brought from International Company for Dairy \& Food products "Milky Land", the $10^{\text {th }}$ Ramadan City, Egypt. Skim milk powder (SMP) was purchased from Bob's Red Mill 
Natural Foods, Milwaouke, USA. Emulsifying salts (disodium phosphate and sodium citrate) were provided from El Gomhoureya Co. For Trading Drugs and Medical Supplies, El Amiryah, Cairo, Egypt. Shortening was purchased from Musim Mas Holding, West-Singapore. Tomato peels were obtained from Kaha Company For Preserved Foods, Qalubiya, Egypt.

\section{Lycopene oil preparation using green-extraction technique}

The lycopene oil was extracted from industrial waste of tomato peels according to the method of Chen and Meyers [25] with modifications. In brief, the tomato peel wastes were washed carefully with water. The tomato peels with an initial moisture content of $83 \%$ were then mixed into melted shortening (1:2) and heated in hot bath of water at $95^{\circ} \mathrm{C}$ for $1 \mathrm{~h}$. Then, the melted mixture was filtered using a muslin cloth, followed by centrifugation at $3000 \times \mathrm{g}$ for $5 \mathrm{~min}$. Afterward, the lycopene oil from the supernatant was separated (Figure. 2) and kept under $-18^{\circ} \mathrm{C}$ until further use.

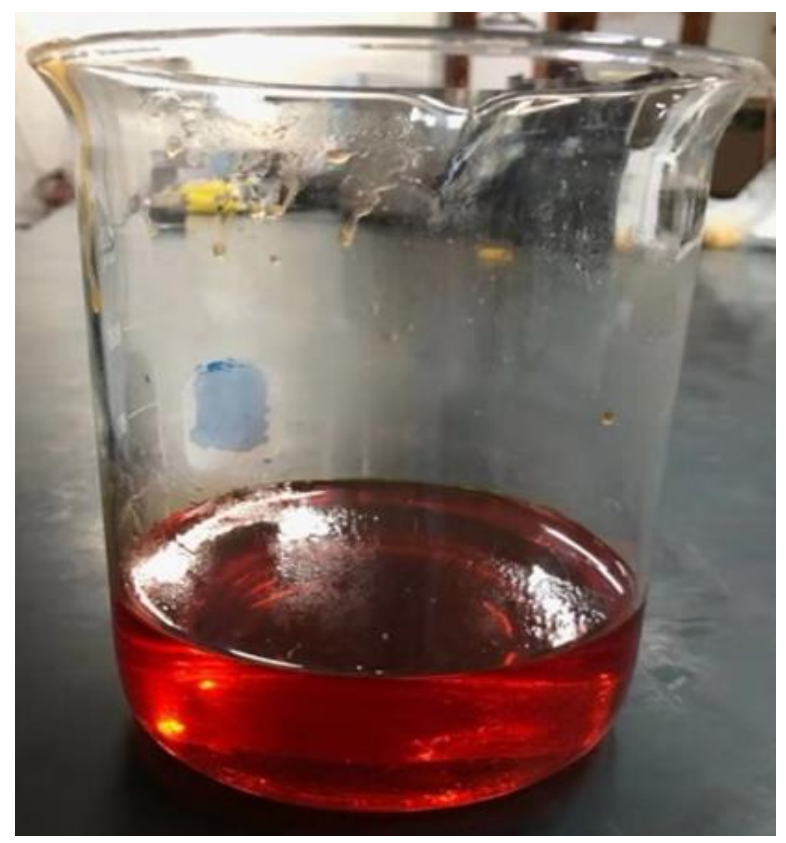

Figure 2: Photograph of lycopene oil obtained by green-extraction technique of tomato peels waste

\section{Processed Cheese Manufacture}

Processed cheese spreads were manufacture according to Guinee [26] with a few minor modifications. Briefly, Kariesh cheese, Cheddar cheese, Ras cheese, butter and SMP were mixed with emulsifying salts (disodium phosphate and sodium citrate) in addition to water which prepared in the processing kettle in order to set the moisture content at approximately $45 \pm 1 \%$. The mixture was cooked by direct steam injection heater to 90 $95^{\circ} \mathrm{C}$ at a pressure of $1.5 \mathrm{bar}$ and kept under agitation for $8 \mathrm{~min}$. After cooking, the samples were then transferred into circular airtight plastic containers (diameter $45 \mathrm{~mm} \times$ height $25 \mathrm{~mm}$ ) with plastic cover and rapidly cooled at $6 \pm 1{ }^{\circ} \mathrm{C}$. The chemical composition of the materials used in manufacture of processed cheese spreads is given in Table 1. The samples were of five varieties, including processed cheese without added lycopene oil (control), with partial substitution of butter by lycopene oil at ratio of $25 \%(\mathrm{w} / \mathrm{w} ; \mathrm{T} 1), 50 \%(\mathrm{w} / \mathrm{w} ; \mathrm{T} 2), 75 \%(\mathrm{w} / \mathrm{w} ; \mathrm{T} 3)$, and with total substitution of butter by lycopene oil (T4). The formulation of the processed cheese spreads preparation is given in Table 2. All samples were analyzed after $0,1,2$ and 3 months of storage at $6 \pm 1$ and $25 \pm 1{ }^{\circ} \mathrm{C}$.

\begin{tabular}{|l|l|l|}
\hline Ingredients & Total solids (TS) \% & Fat $(\mathrm{F}) \%$ \\
\hline Ras Cheese & $54.93 \pm 0.40$ & $22.26 \pm 0.28$ \\
\hline Kariesh Cheese & $74.98 \pm 0.26$ & $0.48 \pm 0.09$ \\
\hline Cheddar Cheese & $66.92 \pm 0.41$ & $32.96 \pm 0.32$ \\
\hline Skim Milk & $97.16 \pm 0.12$ & $0.31 \pm 0.03$ \\
\hline Butter & $83.98 \pm 0.33$ & $82.10 \pm 0.36$ \\
\hline Red oil & $99.56 \pm 0.08$ & $99.03 \pm 0.06$ \\
\hline
\end{tabular}

Table1: Chemical composition of the ingredients used in manufacture of red processed cheese spreads

The samples were of five varieties, including processed cheese without added lycopene oil (control), with partial substitution of butter by lycopene oil at ratio of $25 \%(\mathrm{w} / \mathrm{w} ; \mathrm{T} 1), 50 \%(\mathrm{w} / \mathrm{w} ; \mathrm{T} 2), 75 \%(\mathrm{w} / \mathrm{w} ; \mathrm{T} 3)$, and with total substitution of butter by lycopene oil (T4). The formulation of the processed cheese spreads preparation is given in Table 2.

\begin{tabular}{|c|c|c|c|c|c|c|}
\hline Ingredient & Control & & T1 & T2 & T3 & T4 \\
\hline Kariesh Cheese & 13.93 & & 13.93 & 13.93 & 13.93 & 13.93 \\
\hline Cheddar Cheese & 12.5 & & 12.5 & 12.5 & 12.5 & 12.5 \\
\hline
\end{tabular}




\begin{tabular}{|c|c|c|c|c|c|}
\hline Ras Cheese & 30.77 & 30.77 & 30.77 & 30.77 & 30.77 \\
\hline Skim Milk powder & 2.12 & 2.12 & 2.12 & 2.12 & 2.12 \\
\hline Butter & 13.90 & 10.43 & 6.95 & 3.47 & -- \\
\hline Red oil & -- & 3.47 & 6.95 & 10.43 & 13.90 \\
\hline Emulsifying Salt & 2.5 & 2.5 & 2.5 & 2.5 & 2.5 \\
\hline Water & 24.28 & 24.28 & 24.28 & 24.28 & 24.28 \\
\hline Total & 100 & 100 & 100 & 100 & 100 \\
\hline
\end{tabular}

Table 2: Formulations of processed cheese without added red oil (control), with partial

\section{Basic physicochemical characterization of processed Cheese}

In order to prepare the sample for analysis, ten grams of cheese samples were mixed well with $90 \mathrm{~mL}$ of distilled water. The $\mathrm{pH}$ values were then measured using a digital $\mathrm{pH}$ meter (Mettler Toledo, Shanghai, China). Moisture, ash, protein and fat of cheese samples were measured according to AOAC [27]. Moisture content was measured gravimetrically by drying $3 \mathrm{~g}$ of each sample by oven-drying at $105^{\circ} \mathrm{C}$ to fixed weight. Ash content was measured by burning $3 \mathrm{~g}$ of each sample in a furnace at $550{ }^{\circ} \mathrm{C}$ until fixed weight. Protein content was measured by Kjeldahl using a nitrogento-protein conversion factor of 6.38. Fat was measured according to the Gerber method.

\section{Measurement of antioxidant activity of processed cheese}

Total phenolic content (TPC) of specimens was measured by using FolinCiocalteu method described by López-García, Cilla [28], with some modifications. The samples were prepared by adding ethanol (95\%) for 3 days at room temperature. In short, $0.75 \mathrm{ml}$ of Folin-Denis reagent (tenfold dilution) was blended with $0.1 \mathrm{ml}$ of specimen. The mixture was incubated at room temperature for $5 \mathrm{~min}$ and $0.75 \mathrm{ml}$ solution of sodium carbonate (2\%) was then added to it. After another 15 min of incubation at room temperature, the absorbance of the mixture was then measured at $760 \mathrm{~nm}$. Results were specified as milligram of Gallic acid equivalent (GAE) per $100 \mathrm{ml}$ of specimen. Using $8-80 \mu \mathrm{g} / \mathrm{ml}$ Gallic acid aqueous solutions, the calibration curve was conducted.

The free radical scavenging activity (Antioxidant activity) of the samples was examined by 1,1-diphenyl-2-picrylhydrazyl (DPPH) via the technique of Brand-Williams, Cuvelier [29]. The samples were prepared by adding $95 \%$ methanol for $19 \mathrm{~h}$ at room temperature. Antioxidant solution in methanol $(0.1 \mathrm{~mL})$ was added to $3.9 \mathrm{~mL}$ of a $6 \times 10^{5} \mathrm{~mol} / \mathrm{L}$ methanol DPPH solution. Before left the mixture in the darkness for 30 min at room temperature, it was mixed forcibly. Thereafter, using a spectrophotometer (Shimadzu Co., Ltd., Japan) at $515 \mathrm{~nm}$, the quantity of the residual DPPH in each time of stop was examined. All measurements were implemented in triplicate and expressed as the percentage of the DPPH radical inhibition (DRI) and the equation used to measure it is as follows:

$\operatorname{DRI}(\%)=\left[\frac{A b c-A b s}{A b c}\right] \times 100$

(1)

While, the $A b c$ is the control absorbance (pure DPPH solution), the $A b s$ is the test sample absorbance (DPPH solution plus test sample).

\section{Measurement of lycopene content}

Lycopene content was determined according to Davis, Fish [30]. In short, about $0.6 \mathrm{~g}$ of two samples (replicated) was weighed from each puree into two amber glass screw top vials $(40 \mathrm{~mL})$ and then $10 \mathrm{~mL}$ of hexane with $5 \mathrm{~mL}$ of ethanol $(95 \%)$ were added. Thereafter, using a magnetic stirring plate, samples were stirred well during sampling. The samples were then placed in ice on orbital shaker (ZheJiang HuaWei Scientific Instrument Co., Zhe Jiang, China) at $175 \mathrm{rpm}$ for $20 \mathrm{~min}$ in order to extract the lycopene from the samples. A $3 \mathrm{~mL}$ of distilled water was then added to each vial with shaking for an extra $4 \mathrm{~min}$ in ice. To allow for separation of phase, the samples were left at room temperature for $10 \mathrm{~min}$. Finally, the absorbance of upper layer of hexane was measured at $503 \mathrm{~nm}$. Based on weight of sample, the lycopene content was calculated.

\section{Determination of firmness}

Firmness test was performed using a TMS-Pro Texture Analyzer (FTC, Virginia, USA) at a constant speediness of $60 \mathrm{~mm} / \mathrm{min}$ to a depth of 10 $\mathrm{mm}$ beneath the suspension surface. The trigger force was $0.1 \mathrm{~N}$ and deformation profile was $30 \%$. Compression mode was used with cylinder penetrometer probe ( $45 \mathrm{~mm}$ diameter $\mathrm{x} 25 \mathrm{~mm}$ height) to measure the firmness of the cheese.

\section{Meltability}

Meltability of cheese samples was measured according to Savello, Ernstrom [31] with few modifications. Briefly, cheese sample (15 g) was weighed into the melting glass tubes (cylinder of glass, $25 \mathrm{~cm}$ long $\times 3$ $\mathrm{cm}$ diameter $\times$ glass thickness $0.8 \mathrm{~mm}$, supplied with rubber stopper at both parties). The reference lines were scratched on one side of the glass tubes and then were left upright in an ice bath for $40 \mathrm{~min}$. After that, the tubes were placed horizontally in a rack and moved into an oven set at $105{ }^{\circ} \mathrm{C}$ for $10 \mathrm{~min}$. The rack was removed and tended at $45^{\circ}$ to break the cheese flow. The distance from the edge of the melted sample to the reference line was recorded in in millimeters and recorded as "cheese flow."

\section{Determination of oil loss amount}

The oil lost quantity was measured gravimetric analysis according to [32]. Cheese Sample ( $5 \mathrm{~mm}$ height $\times 22 \mathrm{~mm}$ diameter) was weighed and placed on Whatman no. 4 circular filter paper (150 mm diameter) which preweighed and kept at $5 \pm 1{ }^{\circ} \mathrm{C}$. In order to get a true and accurate result and due to the changes in humidity, the empty filter papers (blank) were used. The filter papers were weighed until constant weight and the oil lost quantity (\%) was measured by the following equation:

The oil lost quantity (\%)

$$
=\left(\left[\left(W_{m}-W_{i}\right)-\left(W_{b 1}-W_{b 2}\right)\right] / W_{s}\right) \times 100
$$

, where $W_{m}$ is the last weight of the filter paper after oil migration, $W_{i}$ is the initial weight of the filter paper (before putting the sample), $W_{b l}$ is the last blank weight, and $W_{b 2}$ is the initial blank weight.

\section{Sensory evaluation}


Sensory analysis of tomato process cheese spread was assessed according to Bandyopadhyay, Chakraborty [33] with few modifications. Sensory evaluation was performed by a group of 10 qualified panelists consisted of female and male aged between 26 until 70 years old (department of dairy science, the food technology research institute). We asked the panelists to assess the samples for satisfactoriness of appearance, color, texture and flavor via scoring the samples from 1 to 5 .

\section{Statistical analysis}

An analysis (one-way) of variance was performed to make a comparison of means among groups using generalized linear model. Duncan's multiple comparison tests were selected to determine the significant level of lycopene oil mixing on the chemical and physical properties of red processed cheese spreads samples at $\mathrm{p}<0.05$ using SAS (version 9.3 TS Level 1M2, SAS Institute Inc., Cary, NC, USA). All experiments were performed in three replicates.

\section{RESULTS \& DISCUSSION}

\section{Green extraction of lycopene with shortening oil as solvent by heat}

The green extraction of lycopene technique has conveyed advantages related to the standards of green extraction such as plant/crop-based renewable resources (tomato peels), substitute for petroleum solvent (shortening), reducing electricity use, time-saving and cost reduction, biorefining (utilization of by-products by treatment of waste), small processing unit with smaller solo processes (two stages) and production of a non-changed environment-friendly product without pollutions (fortified oil). It was proved that the edible vegetable oil has the ability to be used as an alternative or co-solvent in extracting the required ingredients [34]. The green extraction technique of lycopene at a tomato peels to oil ratio of 1:2 (w/w) resulted in high extraction of lycopene content $(839 \mathrm{mg} / 100 \mathrm{~g})$. This can regarded to oil act as solvent of carotenoids and lipophilic interaction activity of lycopene content in broken down of skin cell wall by effect of heat treatment which reduce the bonding forces between lycopene and tissue network that result in release of the lycopene into medium (shortening).
Sachindra and Mahendrakar [20] showed that carotenoid concentration in sunflower oil depended on the effect of temperature and time of heating waste at a waste to oil ratio of 1:2 which indicated that the concentration level of carotenoid raised up when the temperature raised up to $70{ }^{\circ} \mathrm{C}$, while the rate of increasing carotenoid content was minimal above a heating time of $150 \mathrm{~min}$. Machmudah, Zakaria [35] illustrated that the ideal processing recognized to remove lycopene from tomato skin was 40 $\mathrm{MPa}, 90{ }^{\circ} \mathrm{C}$, and a ratio of tomato peel to seed of $37 / 63$ in order to reach $56 \%$ of lycopene extraction. The used of tomato seed oil assisted to amend the retrieval of lycopene from $18 \%$ to $56 \%$ because the presence of seed oils act as co-solvent to recover lycopene and increase the yield.

\section{Chemical Composition of red processed cheese spreads}

Usually, process cheese ingredients depended on Egyptian standard specification and the kind of intended use that the processed cheese will be targeted for. The final functional characteristics of the processed cheese are affected according to its various chemical and structural characteristics. Table 3 shows the chemical composition of red processed cheese spreads. It was observed that there is a slight increasing of dry matter (DM), ash and lycopene in all treatments as the level of replacement increased as T4 gained the highest level $44.57 \%, 5.30 \%$ and $112.30 \mathrm{mg} / 100 \mathrm{~g}$ respectively. In contrast, a small drop in fat was observed in all samples especially T3 and T4 samples. Increasing of DM, ash and lycopene could be due to the using the lycopene oil enriched with lycopene $839 \mathrm{mg} / 100 \mathrm{~g}$. While control sample has the maximum content of fat and fat/dry matter however, it had the lowest total protein and ash levels than other samples. The increasing in the lycopene and ash content could be due to rising in substituted oil which is enriched with lycopene as Al-Wandawi, Abdul-Rahman [36] stated that tomato skin holds great percentage of lycopene offset by a low ratio in tomato seeds and pulp. The major content of lycopene was incorporated in the skin and water insoluble section of the tomato pulp [37].

\begin{tabular}{|c|c|c|c|c|c|c|c|}
\hline Sample & $\overline{\mathrm{DM}}$ & Fat & Fat ratio & Protein & $\mathrm{pH}$ & Ash & Lycopene \\
\hline $\mathrm{C}$ & $44.05 \pm 0.09^{\mathrm{B}}$ & $25.05 \pm 0.07^{\mathrm{A}}$ & $56.83 \pm 0.28^{\mathrm{A}}$ & $14.05 \pm 0.16^{\mathrm{C}}$ & $5.48 \pm 0.07^{\mathrm{A}}$ & $4.99 \pm 0.50^{\mathrm{A}}$ & $0.0 \pm 0.0^{\mathrm{E}}$ \\
\hline $\mathrm{T} 1$ & $44.07 \pm 0.09^{\mathrm{B}}$ & $25.04 \pm 0.11^{\mathrm{A}}$ & $56.81 \pm 0.22^{\mathrm{A}}$ & $14.34 \pm 0.05^{\mathrm{B}}$ & $5.50 \pm 0.09^{\mathrm{A}}$ & $5.00 \pm 0.10^{\mathrm{A}}$ & $28.20 \pm 0.06^{\mathrm{D}}$ \\
\hline $\mathrm{T} 2$ & $44.14 \pm 0.28^{\mathrm{B}}$ & $24.98 \pm 0.07^{\mathrm{A}}$ & $56.59 \pm 0.30^{\mathrm{A}}$ & $14.28 \pm 0.07^{\mathrm{B}}$ & $5.52 \pm 0.06^{\mathrm{A}}$ & $5.12 \pm 0.04^{\mathrm{A}}$ & $60.58 \pm 0.06^{\mathrm{C}}$ \\
\hline $\mathrm{T} 3$ & $44.48 \pm 0.05^{\mathrm{A}}$ & $24.84 \pm 0.06^{\mathrm{B}}$ & $55.84 \pm 0.18^{\mathrm{B}}$ & $14.41 \pm 0.06^{\mathrm{AB}}$ & $5.54 \pm 0.08^{\mathrm{A}}$ & $5.20 \pm 0.09^{\mathrm{A}}$ & $81.40 \pm 0.08^{\mathrm{B}}$ \\
\hline $\mathrm{T} 4$ & $44.57 \pm 0.05^{\mathrm{A}}$ & $24.71 \pm 0.03^{\mathrm{B}}$ & $55.45 \pm 0.12^{\mathrm{B}}$ & $14.53 \pm 0.05^{\mathrm{A}}$ & $5.59 \pm 0.07^{\mathrm{A}}$ & $5.30 \pm 0.08^{\mathrm{A}}$ & $112.30 \pm 0.08^{\mathrm{A}}$ \\
\hline
\end{tabular}

Table 3: Chemical composition of red processed cheese spread

TPC and antioxidant activity changes in red processed cheese spreads during cold storage

The accumulation of phenolic in epidermis (primary dermal tissues) of skin due to their possible function in preservation against UV waves, to perform as capture in fruit dispersal, and as protect chemical compounds against predators, parasitoids and pathogens [38]. The antioxidant constituent (Phenolic \& flavonoids) that come out of waste products of the plant processing could be employed for level up the stability of products by inhibition the oxidative degradation of fats and for protecting against oxidative deterioration in living systems by scavenging oxygen free radicals as well $[39,40]$. As shown in Fig. 3, TPC of fresh samples was ranged from 6.55 to $11.42 \mathrm{mg}$ GAE/100g that higher than control $5.33 \mathrm{mg} \mathrm{GAE} / 100 \mathrm{~g}$. The presence of antioxidant activity and phenolic compounds of control sample is a result to the bioactive peptides content [41] and a lot of free amino acids, mostly methionine, tryptophan and tyrosine [42]. However, the increase in TPC of treatments is attributed to enriched oil with tomato skin extract which contained flavonoids (Quercetin, Kaempafrol and naringenin) and hydroxycinnamic acids (caffeic, chlorogenic, ferulic and p-cumaric acids) [43, 44]. As presented in Fig. 3, the antioxidant activity was increased by increasing lycopene 
oil level (enriched with lycopene and phenolic compounds), then slight decrease in all treatments was noticed during cold storage in both phenolic compounds and antioxidant activity referred to protection system of quercetin and lycopene that are stable at high temperature degrees and acidic conditions, and unstable in alkali and oxygen system [45-48]. Lycopene and other lipid-soluble components could be integrated in the fat droplets as emulsions. An appropriate engineering of the emulsion has been performed and when more antioxidants were incorporated into the aqueous and / or oily stages of the emulsion showed a high ability to decrease oxidation of lipid. As well the physical location display the basic reason behind; that non-polar antioxidants tend to be additionally concentrated in the fat droplet and thus more powerful in preventing lipid oxidation in oil-in-water emulsions than in bulk oil, whereas the opposite was mostly detected for polar antioxidants (PAO) [49-51]. Moreover, Lycopene's configuration worked to reduce free radicals activity [52]. As an antioxidant, lycopene has odd oxygen capture ability two times high than of $\beta$-carotene and ten times greater than that of $\alpha$-tocopherol.
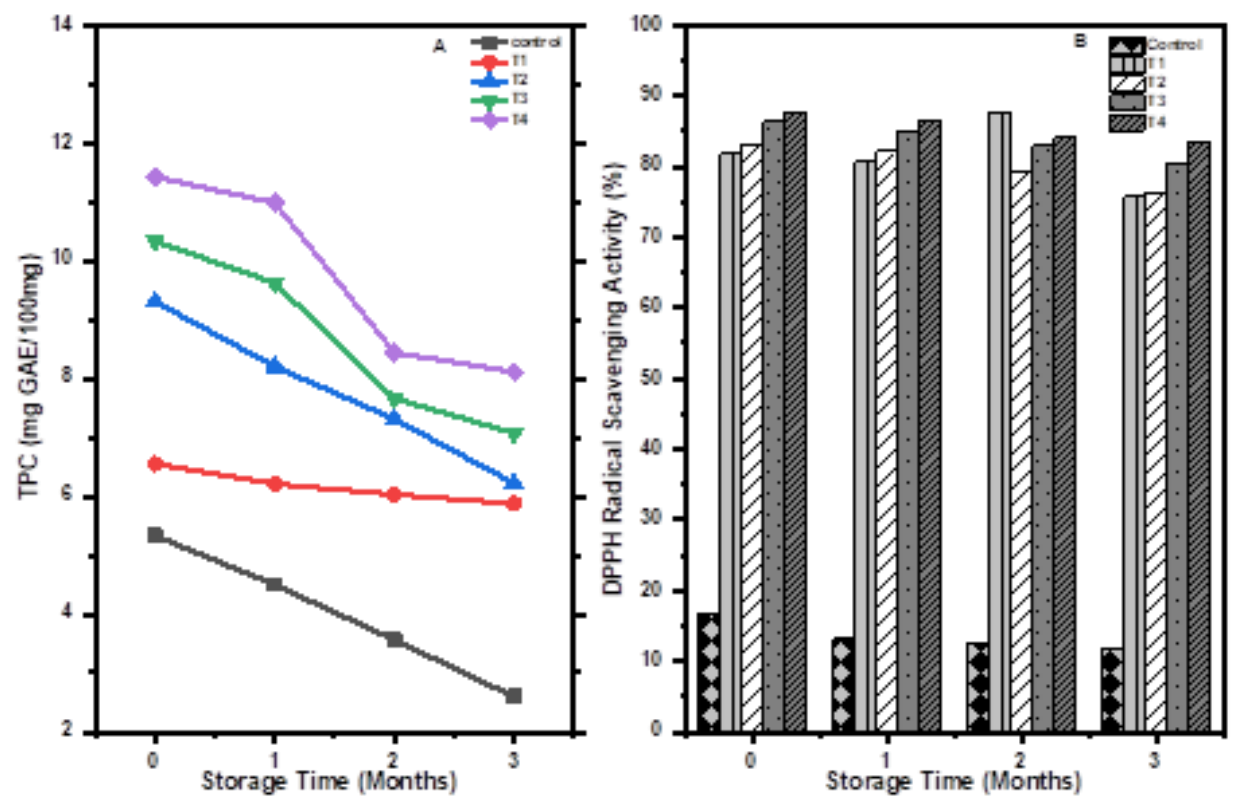

Figure 3. TPC \& antioxidant activity of Red processed cheese spread through storage period

\section{Penetrometer of Red processed cheese spread through storage period}

Penetrometry technique is one of the most important techniques used to determine the firmness of process cheese. Fig. 4A shows the data of penetrometer of red processed cheese spread through storage period. It was noted that the firmness value was decreased with increased level of incorporated red oil. Suggestion of decreasing firmness value due to high content of cis-isomers-lycopene that hold physical properties and chemical behaviors special from those of their all-trans counterpart, involving reduction color intensity and decreasing melting points, they more dissolvable in hydrocarbon solvents and oil, less likely to crystallization, and more polar than their all-trans counterparts [53]. Okonogi and Riangjanapatee [54] reported that the melting temperature of the nanostructured lipid carriers (NLC) was at $48.4{ }^{\circ} \mathrm{C}$ which is like to that of orange wax which was at $51.2^{\circ} \mathrm{C}$ as the internal phase of lycopene loaded NLC obtained was in solid case. This confirm that lycopene content dispersal in oil-in-water affected its physical properties as melting point which be reflected on rheology aspects of red processed cheese.

\section{Meltability of Red processed cheese spread through storage period}

Ko and Gunasekaran [55] illustrated that meltability of cheese indicates to the easiness and range to which the cheese will melt and flow/spread over high temperature. Meltability parameters are important indicators for the desired textural and cooking properties. It could be defined as the easiness of cheese spreads or flows when exposed to heating [56]. Fig. 4B shows meltability characterization. Results revealed that the lycopene oil incorporation affected the texture properties, thus meltabilty value increased by the elevation level of lycopene oil replacement, as meltability of all the fresh processed cheese samples varied from 100 to $122 \mathrm{~mm}$. Meltability of all samples during storage period was decreased. These results are in agreement with Ismail [57] who studied the effect of using unhydrogenated palm oil fractions on processed cheese properties. His study based on 5 samples of processed cheese which have been manufactured by hydrogenated palm kernel oil, palm kernel olein, double fractionated palm olein, mixture of hydrogenated palm kernel oil and palm kernel olein (1:1) in addition to mixture of hydrogenated palm kernel oil and double fractionated palm olein $(1: 1)$. He found that the meltability of processed cheese samples varied from 16 to $45 \mathrm{~mm}$. Also, there were no any differences between meltability of control $(16 \mathrm{~mm})$ and palm kernel olein-based processed cheese (16 and $17 \mathrm{~mm})$ samples, but double fractionated palm olein-based cheeses showed obvious greater meltability ( 34 and $45 \mathrm{~mm}$ ) than those of other cheeses.

\section{Oil separation Index (OSI) of Red processed cheese spread through storage period}

Based on the regulations of processed cheese that obligate to standardizing the moisture and fat content of a process cheese formulation. Fig. 4C illustrates the results of oil separation index. Data indicates that 
control gained high values than other treatments; values of all the fresh processed cheese samples were ranged from 14 to $6 \mathrm{~mm}$. But when going through storage period, the OSI increased till the third month, as noticed it were high at $25{ }^{\circ} \mathrm{C}$ than at $5{ }^{\circ} \mathrm{C}$. The reduction values of OSI for treatments due to the two factors of $\mathrm{pH}$ and total calcium content. The high level of total calcium in cheese components makes it difficult to process of the processed cheese, as excess calcium requires isolating it from natural cheese casein by adding emulsifying salts during cheese processing [58-61]. Furthermore, It was found that the final $\mathrm{pH}$ of a process cheese have an significant impact on structure, the kind of protein interactions, and goodness in order to form process cheese emulsion [62, 63]. Palmer and Sly [63] reported that the constancy of the process cheese emulsion is reduced when the $\mathrm{pH}$ of the process cheese is under 5.4 or exceeding 5.8 .
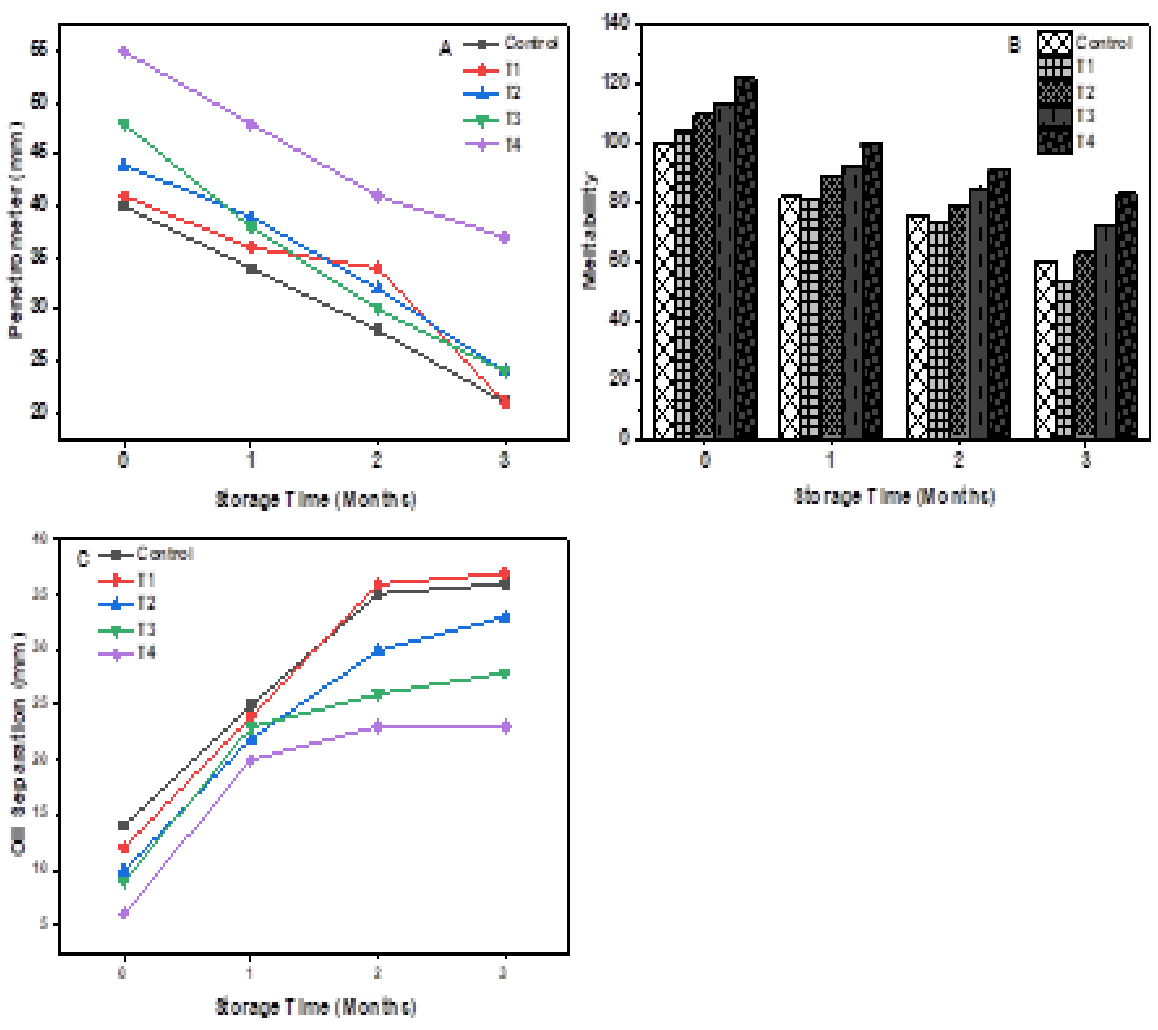

Figure 4: Changes in penetrometer (A), Meltability (B) and oil separation (C) of Red processed cheese spread through storage period

\section{Sensory evaluation of Red processed cheese spread}

The characteristic processed cheese spread samples (Table 4) was sensorically approved by all panelists. Stronger flavors and texture were perceived in T4, because of the higher level of lycopene oil than those formulated with a lower lycopene oil. No significant differences $(p>0.05)$ were found between $\mathrm{C}$ and T1. Generally all panelists agreed that the overall acceptance increased with increased of lycopene oil level in cheese, while no significant differences in color were observed between samples. The appearance of $\mathrm{T} 3 \& \mathrm{~T} 4$ was better than $\mathrm{C}, \mathrm{T} 1 \& \mathrm{~T} 2$.

\begin{tabular}{|c|c|c|c|c|c|}
\hline Sample & Appearance & Color & Flavor & Texture \\
\hline $\mathrm{C}$ & $3.5 \pm 0.30^{\mathrm{B}}$ & $4.00 \pm 0.32^{\mathrm{A}}$ & $2.09 \pm 0.27^{\mathrm{D}}$ & $2.02 \pm 0.12^{\mathrm{D}}$ & $2.04 \pm 0.20^{\mathrm{D}}$ \\
\hline $\mathrm{T} 1$ & $3.7 \pm 0.20^{\mathrm{B}}$ & $3.63 \pm 0.25^{\mathrm{A}}$ & $2.31 \pm 0.04^{\mathrm{DC}}$ & $2.02 \pm 0.16^{\mathrm{D}}$ & $2.00 \pm 0.12^{\mathrm{D}}$ \\
\hline $\mathrm{T} 2$ & $3.7 \pm 0.20^{\mathrm{B}}$ & $3.43 \pm 0.35^{\mathrm{A}}$ & $2.53 \pm 0.04^{\mathrm{C}}$ & $2.57 \pm 0.07^{\mathrm{C}}$ & $2.49 \pm 0.03^{\mathrm{C}}$ \\
\hline $\mathrm{T} 3$ & $4.2 \pm 0.25^{\mathrm{A}}$ & $3.44 \pm 0.29^{\mathrm{A}}$ & $3.31 \pm 0.06^{\mathrm{B}}$ & $3.50 \pm 0.06^{\mathrm{B}}$ & $3.18 \pm 0.07^{\mathrm{B}}$ \\
\hline $\mathrm{T} 4$ & $4.3 \pm 0.36^{\mathrm{A}}$ & $4.09 \pm 0.18^{\mathrm{A}}$ & $4.21 \pm 0.07^{\mathrm{A}}$ & $4.03 \pm 0.16^{\mathrm{A}}$ & $4.03 \pm 0.15^{\mathrm{A}}$ \\
\hline
\end{tabular}

$* 1=$ poor $5=$ excellent

Table 4: Sensory evaluation of Red processed cheese spread

\section{Conclusions}

Our study aimed to employing lycopene extraction as nutritional, color agent and softener. We extracted lycopene from tomato peels using melted shortening by green-extraction technique. This technique was implemented at $95{ }^{\circ} \mathrm{C}$ for $60 \mathrm{~min}$, and the temperature was then raise to $140{ }^{\circ} \mathrm{C}$ until complete extraction of lycopene. The aim of this technique 
was to break cell wall and release all contents such as lycopene and minerals, and keeping the lycopene content without degradation in addition to increase the bio-availability of lycopene stability. Use of lycopene oil increased dry matter, ash, lycopene content, antioxidant activity, meltability and sensorial characteristics of processed cheese. Whereas, the firmness value was decreased with increasing level of incorporated lycopene oil. We can thus conclude that the substitution of butter by lycopene oil obtained by green-extraction technique of tomato peels waste in processed cheese can be used as a substitute process for decreasing saturated fats in dairy products with keeping other desired characteristics of the product.

\section{References}

1. Buňka, F., J. Hrabě, and S. Kráčmar (2004). The effect of sterilisation on amino acid contents in processed cheese. International Dairy Journal, 14(9): 829-831.

2. Talbot-Walsh, G., D. Kannar, and C. Selomulya (2018). A review on technological parameters and recent advances in the fortification of processed cheese. Trends in Food Science \& Technology, 81: 193-202.

3. Kapoor, R. and L.E. Metzger (2008). Process Cheese: Scientific and Technological Aspects-A Review, 7(2) 194-214.

4. Tedeschi, P., et al. (2011). Chemotype and genotype combined analysis applied to tomato (Lycopersicon esculentum Mill.) analytical traceability. Journal of Food Composition and Analysis, 24(2): 131-139.

5. Ranveer, R.C., S.N. Patil, and A.K. Sahoo (2013). Effect of different parameters on enzyme-assisted extraction of lycopene from tomato processing waste. Food and Bioproducts Processing, 91(4): 370-375.

6. Saini, R.K., S.H. Moon, and Y.-S. Keum (2018). An updated review on use of tomato pomace and crustacean processing waste to recover commercially vital carotenoids. Food Research International, 108: 516-529.

7. Castañeda-Ovando, A., et al. (2009). Chemical studies of anthocyanins: A review. Food Chemistry, 113(4): 859-871.

8. Ranveer, R.C., (2018). Chapter 13 - Lycopene: A Natural Red Pigment, in Natural and Artificial Flavoring Agents and Food Dyes, A.M. Grumezescu and A.M. Holban, Editors. Academic Press. p. 427-456.

9. Eh, A.L.-S. and S.-G. Teoh (2012). Novel modified ultrasonication technique for the extraction of lycopene from tomatoes. Ultrasonics Sonochemistry, 19(1): 151-159.

10. Tamimi, R.M., et al. (2005). Plasma carotenoids, retinol, and tocopherols and risk of breast cancer. American Journal of Epidemiology, 161(2): 153-160.

11. Ranveer, R.C., S.N. Patil, and A.K. Sahoo (2013). Effect of different parameters on enzyme-assisted extraction of lycopene from tomato processing waste. Food and Bioproducts Processing, 91(C4): 370-375.

12. Narisawa, T., et al. (1998). Prevention of N-methylnitrosoureainduced colon carcinogenesis in F344 rats by lycopene and tomato juice rich in lycopene. Japanese Journal of Cancer Research, 89(10): 1003-1008.

13. Lian, F.Z., et al. (2007). Apo-10'-lycopenoic acid inhihits lung cancer cell growth in vitro, and suppresses lung tumorigenesis in the A/J mouse model in vivo. Carcinogenesis, 28(7): 15671574.

14. Rao, A.V. and S. Agarwal (1999). Role of lycopene as antioxidant carotenoid in the prevention of chronic diseases: A review. Nutrition Research, 19(2): 305-323.
15. George, B., et al. (2004). Antioxidants in tomato (Lycopersium esculentum) as a function of genotype. Food Chemistry, 84(1): 45-51.

16. Phinney, D.M., et al. (2017). Effect of solvent addition sequence on lycopene extraction efficiency from membrane neutralized caustic peeled tomato waste. Food Chemistry, 215: 354-361.

17. Dong, J., et al. (2018). Solvent tuning configurational conversion of lycopene aggregates in organic-aqueous mixing solvent. Chemical Physics Letters, 701: 52-57.

18. Poojary, M.M. and P. Passamonti (2015). Optimization of extraction of high purity all-trans-lycopene from tomato pulp waste. Food Chemistry, 188: 84-91.

19. Zuknik, M.H., N.A. Nik Norulaini, and A.K. Mohd Omar (2012), Supercritical carbon dioxide extraction of lycopene: A review. Journal of Food Engineering, 112(4): 253-262.

20. Sachindra, N.M. and N.S. Mahendrakar (2005). Process optimization for extraction of carotenoids from shrimp waste with vegetable oils. Bioresource Technology, 96(10): 11951200 .

21. Li, Y., et al. (2014). Direct green extraction of volatile aroma compounds using vegetable oils as solvents: Theoretical and experimental solubility study. LWT - Food Science and Technology,. 59(2, Part 1): 724-731.

22. Li, Y., et al. (2013). Green ultrasound-assisted extraction of carotenoids based on the bio-refinery concept using sunflower oil as an alternative solvent. Ultrasonics Sonochemistry, 20(1): 12-18.

23. Choksi, P.M. and V.Y. Joshi (2007). A Review on LycopeneExtraction, Purification, Stability and Applications. International Journal of Food Properties, 10(2): 289-298.

24. Al-Neshawy, A.A. and S.M. Al-Eid (2000). Improving the quality and oxidative stability of vegetable oil shortening using fermented dairy products and wheat gluten. Food Chemistry, 71(1): 57-60.

25. Chen, H.M. and S.P. Meyers (1982). Extraction of astaxanthin pigment from crawfish waste using a soy oil process. Journal of Food Science, 47(3): 892.

26. Guinee, T.P. (2011). Effects of Natural Cheese Characteristics and Processing Conditions on Rheology and Texture: The Functionality of Cheese Components in the Manufacture of Processed Cheese, in Processed Cheese and Analogues, A.Y. Tamime, Editor.

27. AOAC (1995). Official methods of analysis of AOAC international (16th edn). Washington, DC, USA: Association of Official Analytical Chemists.

28. López-García, G., et al. (2017). Protective effect of antioxidants contained in milk-based fruit beverages against sterol oxidation products. Journal of Functional Foods, 30: 81-89.

29. Brand-Williams, W., M.E. Cuvelier, and C. Berset (1995). Use of a free radical method to evaluate antioxidant activity. LWT Food Science and Technology, 28(1): 25-30.

30. Davis, A.R., W.W. Fish, and P. Perkins-Veazie, A (2003). Rapid Hexane-free Method for Analyzing Lycopene Content in Watermelon. 68(1): 328-332.

31. Savello, P.A., C.A. Ernstrom, and M. Kalab, (1989). Microstructure and Meltability of Model Process Cheese Made with Rennet and Acid Casein. Journal of Dairy Science,. 72(1): $1-11$.

32. Ramel, P.R. and A.G. Marangoni (2018). Processed cheese as a polymer matrix composite: A particle toolkit for the replacement of milk fat with canola oil in processed cheese. Food Research International, 107: 110-118. 
33. Bandyopadhyay, M., R. Chakraborty, and U. Raychaudhuri (2007). Role of carrot on shelf stability of dairy dessert (rasogolla) during refrigerated storage. 31(6): 714-735.

34. Sun, M. and F. Temelli (2006). Supercritical carbon dioxide extraction of carotenoids from carrot using canola oil as a continuous co-solvent. The Journal of Supercritical Fluids,. 37(3): 397-408.

35. Machmudah, S., et al. (2012). Lycopene extraction from tomato peel by-product containing tomato seed using supercritical carbon dioxide. Journal of Food Engineering,. 108(2): 290-296.

36. Al-Wandawi, H., M. Abdul-Rahman, and K. Al-Shaikhly (1985). Tomato processing wastes as essential raw materials source. Journal of Agricultural and Food Chemistry, 33(5): 804-807.

37. Liu, Y., et al. (2010). Preparative separation and purification of lycopene from tomato skins extracts by macroporous adsorption resins. Food Chemistry, 123(4): 1027-1034.

38. Cheng, J., et al. (2017). Effect of rootstock on phenolic compounds and antioxidant properties in berries of grape (Vitis vinifera L.) cv. 'Red Alexandria'. Scientia Horticulturae, 217: 137-144.

39. Makris, D.P., G. Boskou, and N.K. Andrikopoulos (2007). Polyphenolic content and in vitro antioxidant characteristics of wine industry and other agri-food solid waste extracts. Journal of Food Composition and Analysis, 20(2): 125-132.

40. Maqsood, S., et al. (2014). Phenolic Compounds and Plant Phenolic Extracts as Natural Antioxidants in Prevention of Lipid Oxidation in Seafood: A Detailed Review. 13(6): 11251140.

41. Meira, S.M.M., et al (2012). Bioactive peptides in watersoluble extracts of ovine cheeses from Southern Brazil and Uruguay. Food Research International, 48(1): 322-329.

42. Bottesini, C., et al. (2013). Antioxidant capacity of water soluble extracts from Parmigiano-Reggiano cheese. International Journal of Food Sciences and Nutrition, 64(8): 953-958.

43. Martinez-Valverde, I., et al. (2002). Phenolic compounds, lycopene and antioxidant activity in commercial varieties of tomato (Lycopersicum esculentum). Journal of the Science of Food and Agriculture, 82(3): 323-330.

44. Barros, L., et al. (2012). Characterization and Quantification of Phenolic Compounds in Four Tomato (Lycopersicon esculentum L.) Farmers' Varieties in Northeastern Portugal Homegardens. Plant Foods for Human Nutrition, 67(3): 229234.

45. Siwach, R., J. Tokas, and R. Seth (2016). Use of lycopene as a natural antioxidant in extending the shelf-life of anhydrous cow milk fat. Food Chemistry, 199: 541-546.

46. Prikryl, J., et al. (2018). Antioxidant properties and textural characteristics of processed cheese spreads enriched with rutin or quercetin: The effect of processing conditions. Lwt-Food Science and Technology, 87: 266-271.

47. Buchner, N., et al. (2006). Effect of thermal processing on the flavonols rutin and quercetin. Rapid Communications in Mass Spectrometry, 20(21): 3229-3235.
48. Barnes, J.S., F.W. Foss, and K.A. Schug (2013). Thermally Accelerated Oxidative Degradation of Quercetin Using Continuous Flow Kinetic Electrospray-Ion Trap-Time of Flight Mass Spectrometry. Journal of the American Society for Mass Spectrometry, 24(10): 1513-1522.

49. McClements, D.J. and E.A. Decker (2000). Lipid oxidation in oil-in-water emulsions: Impact of molecular environment on chemical reactions in heterogeneous food systems. Journal of Food Science, 65(8): 1270-1282.

50. Huang, S.W., et al. (1996). Antioxidant activity of carnosic acid and methyl carnosate in bulk oils and oil-in-water emulsions. Journal of Agricultural and Food Chemistry, 44(10): 29512956.

51. Huang, S.W., et al. (1996). Antioxidant activity of alphatocopherol and Trolox in different lipid substrates: Bulk oils vs oil-in-water emulsions. Journal of Agricultural and Food Chemistry, 44(2): 444-452.

52. Chowdhury, M.M.R., et al. (2017). Supplementation of lycopene in maturation media improves bovine embryo quality in vitro. Theriogenology, 103: 173-184.

53. Nguyen, M.L. and S.J. Schwartz (1999). Lycopene: Chemical and biological properties. Food Technology, 53(2): 38-45.

54. Okonogi, S. and P. Riangjanapatee (2015). Physicochemical characterization of lycopene-loaded nanostructured lipid carrier formulations for topical administration. International Journal of Pharmaceutics,. 478(2): 726-735.

55. Ko, S. and S. Gunasekaran (2008). Analysis of cheese melt profile using inverse-Hill function. Journal of Food Engineering,. 87(2): 266-273.

56. Wang, Y.C., et al. (1998). A device for evaluating melt/flow characteristics of cheeses. Journal of Texture Studies, 29(1): 43-55.

57. Ismail, M.M. (2012). The use of a blend of milk ingredients and different palm oil fractions in processed cheese form. J. Food and Dairy Sci. 3: 637 - 645.

58. Sood, V.K. and F.V. Kosikowski (1979), Accelerated Cheddar Cheese Ripening by Added Microbial Enzymes. Journal of Dairy Science,. 62(12): 1865-1872.

59. Caric, M., M. Gantar, and M. Kalab (1985). Effects of emulsifying agents on the microstructure and other characteristics of process cheese--a review. Materials Science, 4: 297-312.

60. Zehren, V.L. and D.D. Nusbaum (2000). Processed Cheese (2 ed.), Cheese Reporter Publishing Co. Inc., Madison, WI.

61. Cavalier-Salou, C. and J.C. Cheftel (1991). Emulsifying Salts Influence on Characteristics of Cheese Analogs from Calcium Caseinate. 56(6): 1542-1547.

62. Marchesseau, S., et al. (1997). Influence of $\mathrm{pH}$ on protein interactions and microstructure of process cheese. Journal of Dairy Science, 80(8): 1483-1489.

63. Palmer, H.J. and W.H. Sly (1943). Oil separation in processed cheese. Dairy Ind, 8: 427-431. 
This work is licensed under Creative Commons Attribution 4.0 License

To Submit Your Article Click Here: Submit Manuscript

DOI:10.31579/2637-8914/035
Ready to submit your research? Choose Auctores and benefit from:

* fast, convenient online submission

* rigorous peer review by experienced research in your field

* rapid publication on acceptance

* authors retain copyrights

* unique DOI for all articles

* immediate, unrestricted online access

At Auctores, research is always in progress.

Learn more www.auctoresonline.org/journals/nutrition-and-foodprocessing 